\title{
Exploring Power Assumptions in the Leadership and Management Debate
}

\begin{abstract}
Purpose

The purpose of this paper is to take a fresh look at the leadership and management debate through exploring underlying power assumptions in the literature.

Approach

The paper is a conceptual discussion that draws on the power based literature to develop a framework to help conceptually understand leadership in relation to management.
\end{abstract}

\section{Findings}

The paper highlights the historically clichéd nature of comments regarding conceptual similarities and differences between leadership and management. The paper draws attention to a problem within this debate - a confusion regarding assumptions of power. As a result the paper brings to the forefront perspectives of management that are of an emergent and non-work perspective which enables the development of a framework of the literature that includes (1) managers 'doing' leadership, (2) managers 'becoming' leaders, (3) 'being' leaders and managers, and, (4) leaders 'doing' management. The paper goes on to explore the meaning and potential behind each part of the framework 
and suggests a need to develop an understanding of 'doing' leadership and management and 'being' managers and leaders through an exploration of 'becoming' in organisations.

\section{Originality}

This paper provides a new perspective on the leadership and management or leadership versus management question by introducing a non-work, emergent or personal perspective on management. Furthermore, this paper concludes that whether leadership and management are similar or different is dependent upon which power construct underlies each phenomenon, a consideration that has been neglected in the leadership and management debate for some time.

Keywords - leadership, management, power, 'doing', 'being' and 'becoming'

Article Classification - Conceptual Paper

\section{Introduction}

This paper reflects on the leadership and management debate and develops a conceptual framework based on underlying power assumptions that are made within the literature. For example, when trying to make the concepts of leadership and management distinct from each other or, indeed related in some way, power relations are assumed. We make a contribution to this debate by introducing the work of Watson 
(2001) and others that promote a non-positional perspective of management into the debate. This then helps in the development of a conceptual framework that sets out four distinct paradigms regarding the leadership and management debate.

Leadership is an increasingly prevalent topic within management studies (e.g. Cooper, 2011). At various times, however, leadership and management have been described as being extensively researched yet having a high level of uncertainty about their conceptual underpinnings (see Burns, 1978 and Grint, 1995 for comment). In this vein we can point to instances where both leadership and management theory and research have been described as having a history of being fragmented and confusing (Gill, 2006; Hales, 1986, 1999; Quinn, 1984; Whitley, 1984), being unconnected (Quinn, 1984; Hales 1986), needing a better appreciation of context (Fry and Kriger, 2009; Hales, 1999; Jepson, 2009; Osborn, et al., 2002; Osborn and Marion, 2009; Porter and McLaughlin, 2006; Zaccaro and Klimoski, 2001) and being derived from differing academic disciplines (Ghoshal, 2005; Gill, 2006). The similarity of these comments made separately about leadership and management is profound and raises the recurring question: are scholars discussing one and the same concept? This conundrum is still being discussed in contemporary academic exchanges, Bedeian and Hunt (2006), for example, discuss the confusion caused by the different ways leadership is conceptualised in relation to management. In the abstract to the exchange of letters it is highlighted that Hunt argues for 'a framework that helps focus on the different historical-contextual aspects within which one would specifically be called upon to differentiate between leadership and management.' (Bedeian and Hunt, 
2006: 190). This paper responds to this call by firstly reviewing the historically clichéd nature of comments regarding conceptual similarities and differences between leadership and management and whether they are connected or mutually exclusive. The paper then offers a conceptual framework that we hope will help provide clarity around differentiating leadership and management. The structure of the paper is such that we firstly highlight the relevant discussion within the management and leadership debate. We then discuss how exploring power can provide an additional perspective before bringing these together in a framework in section four.

In their paper, Bedeian and Hunt (2006: 1900) also conclude by arguing for 'the assumption that leadership is a subset of management, with both needing to be carried out to ensure organisational success.' The framework developed within this paper expands on this assumption by introducing thinking around management as a nonwork or non-positional construct into the leadership and management debate - a view recognised within the general management literature (Alvesson and Willmott, 1996; Easterby-Smith, 1994; Grey, 1999; Mangham, 1986; Mant, 1977; Thomas, 2003; Tsoukas, 1994; Watson, 2001; Willmot, 1984) for a number of years (e.g. Grey, 1999; Hales, 1999; Watson, 1994; Willmott, 2001) but so far unexplored within leadership studies. This body of theory suggests that activities classically thought of as 'managerial' transcend the workplace and are performed in all sorts of contexts, both inside and outside the organisation (Grey, 1999). As mentioned above this perspective has not been recognised in leadership studies nor has it been recognised in the leadership/management debate. For instance, the literature on management and 
leadership has, for some time, made the distinction between leadership derived from an emergent basis and leadership derived from assigned or formal positions in organisations (e.g. Bavelas, 1959). Yet, when comparing leadership with management, the distinction is not made explicit for management, assuming a positional, assigned or formal perspective (management in and of organisations). It is the addition of an informal perspective of management to the debate that informs the development of the framework, discussed in more detail later in this paper. We see this framework as our contribution to the field of leadership studies as it enables scholars to locate their work within what is seen as an ambiguous and long standing debate without losing the inherent complexity of the debate itself. It also enables scholars to frame future research and engage more broadly outside their initial paradigm.

\section{Relating Leadership and Management}

Described by Bedeain and Hunt (2006: 198) as 'a longstanding enigma', the literature on leadership and management has, for a number of years now, swayed from theorising the concepts as the same (Drucker, 1988), mutually exclusive (Bennis and Nanus, 1985; Zaleznik, 1977) or connected (Bass, 1990; Hickman, 1990; Kotter, 1988, 1990; Mintzberg, 1980; Rost, 1991). Either way this has led to a number of clichéd and vague distinctions (see Cammock et al., 1995 for a critical review). We contend that even recent distinctions based on transactional and transformational leadership (AlimoMetcalfe, 1998; Antonakis and House, 2003; Bryman, 1992; Gill, 2006; Sadler, 1997), 
emotional engagement (Young and Dulewicz, 2008), culture (Schein, 2004) or problem-solving (Grint, 2005; 2008; Weick, 1993) offer little help in understanding the similarities and differences between leadership and management based on practical experiences within organisations. This is because they still demarcate the distinction based on basic notions of change in organisations (Brocklehurst et al., 2009), relating largely to Kotter's (1990) distinction that leadership is about creating useful change in organisations whilst management is about producing orderly results. This view, in the least, denigrates management as a concept (Rost, 1991) to the extent that recent research with an Executive MBA group in the UK found that they actively avoided calling themselves managers (Brocklehurst et al., 2009). At the most, this view does little for our understanding of complex concepts such as leadership, management and change in organisations. As Brocklehurst et al. (2009) point out, this view is unsurprising given the sine qua non of the current business world is change (Sturdy and Grey, 2003). The view has also been challenged by contemporary notions of leadership in the resistance of change (Levay, 2010; Zoller and Fairhurst, 2007) which further contends the view that leadership is about creating change (Kotter, 1990). In addition, and for the purposes of this paper, more importantly, these clichéd and vague distinctions do not recognise assumptions about power that underlie how both leadership and management are constructed in theory and practice.

\section{Exploring Underlying Power Assumptions}


In this paper, therefore, whilst recognising the issues of change, we explore assumptions regarding power as a point of departure for further theoretical debate, empirical research and practice in organisations. Although we recognise that other concepts such as language (Jepson, 2010), culture (Schein, 2004) and identity (Ford et al., 2008) may contribute to the understanding of leadership and management, our paper concentrates on the assumptions around power. As Clegg and Ross-Smith (2003) highlight, it was the philosopher Bertrand Russell (1938) who said that just as the fundamental concept in physics is that of energy, so power is the fundamental concept in social science. The term 'power' is highly contested in itself and can be conceptualized from a behavioural perspective (French and Raven, 1959; Raven, 1992, 1993) and a charismatic perspective (Yukl, 1994). It further includes perspectives on gender, networks, decision processes, boundary management, uncertainty, control of technology, control of counter-organisations power (Morgan, 1986), sexual power (Foucault, 1984), knowledge and information (Jackson and Carter, 2000; Morgan, 1986; Pettigrew, 1972), ecological control (Cartwright, 1965; Oldham, 1976), and truth (Jackson and Carter, 2000). In addition, there are the more sociological and poststructural perspectives, such as disciplinary and bio-power (Foucault, 1979, 1984), informational social influence (Festinger, 1954) and symbolic power (language, symbols, settings, stories and ceremonies) (Bourdieu, 1991; Pfeffer, 1981; Pondy, 1978; Weick, 1979).

In relation to power, leadership has, in the past, been divided into two classifications (Bedeian and Hunt, 2006; House and Baetz, 1979). Firstly, those that concern 
individuals who are assigned (or where leadership identity is derived from) formal or legal authority to direct others - referred to as 'formal leaders' or more recently 'purported' leaders (Kort, 2008; Ridgeway, 2003). And, secondly, those that concern individuals who exert (or where leadership identity is derived from exerting) significant influence over others in task groups but where there is no formally allocated authority referred to as 'emergent leaders' (House and Baetz, 1979; McGill and Slocum, 1998).

Despite this distinction, the leadership literature has been criticised as having little regard for constructs of power (e.g. Gordon, 2002; Pye, 2005) which is epitomised by suggestions that leadership scholars pay little attention to the distinction between leadership position and leadership as an influence process (Bryman, 1986; Hollander and Offermann, 1993; Thomas, 2003). It appears therefore that the concept of leadership has the potential for confusion based on different underlying power constructs. It is this confusion that Bedeian and Hunt (2006) highlight. Their exchange of letters points out that some studies view leaders as those holding formal positions (e.g. Judge and Bono, 2003) whilst other studies use leadership as a concept based on personal qualities (e.g. Judge, et al., 2002). Bedeian and Hunt (2006) also discuss a related issue, which is that the terms - leadership and management - are sometimes used interchangeably (highlighted originally by Segal, 1981) and writers fail to let the reader explicitly know that this has occurred. Within this paper we underline the fundamental nature behind this confusion and propose that both views of leadership and management are conceptually acceptable. We go on to point out that it is a lack of understanding of the assumptions regarding power that cause this confusion. We 
believe the framework highlighted in this paper helps to avoid the terms being used interchangeably without good conceptual underpinning and will provide a basis by which writers can make explicit their conceptual frame of reference.

Interestingly, writing on management, similar to writing on leadership, has suffered criticism in the past for a lack of discussion regarding underlying assumptions about power (e.g. Clegg and Ross-Smith, 2003). There is also a similar distinction regarding power, as for leadership, made in the management literature (Alvesson and Willmott, 1996; Mant, 1977). It is suggested that activities classically thought of as 'managerial' are in fact performed by all sorts of people in all sorts of contexts, both inside and outside the workplace (Grey, 1999). Management therefore can also be viewed from two perspectives that are not dissimilar to those for leadership. Management or managerial identity can be viewed as a position within an organisation (Mant, 1977; Willmott, 1984) or as a set of activities that transcend the workplace (Alvesson and Willmott, 1996; Mant, 1977; Willmott, 1984). So while the term 'management' is used for a position in an organisation, there is also a more personal, non-work perspective. Whitley (1984) provides an account of the history of the study of management that explains the nuances behind this move from understanding management from a positional power or assigned perspective to more modern non-work constructs. He reasons that a shift to management study in universities and $\mathrm{PhD}$ programmes as opposed to 'scientific fields' and 'management elite' has led to the separation of management research from the day to day concerns of managers to more esoteric intellectual standpoints. As Watson (2001: 12) signifies“...in a sense, all human beings 
are managers too; people struggling to cope, to manage, to shape their destinies... all humans are managers in some way. But some of them also take on the formal occupational work of being managers. They take on a role of shaping aspects of human social structure and culture in parts of our societies - those parts we call work organisations." The idea of management being derived from a 'non-work', personal or emergent perspective enables a broader picture of both leadership and management to be developed and where a four-part conceptual framework can be offered.

\section{Framing the Leadership and Management Debate through Power Perspectives}

Up to this point the paper has shown that both management and leadership can be constructed and misconstrued through differing assumptions about power. Using a distinction of power assumptions as the basis for discussion, a four-part conceptual framework has been developed. These constructs are represented by four quadrants

in the framework that include (1) managers 'doing' leadership, (2) managers 'becoming' leaders, (3) 'being' leaders and managers, and, (4) leaders 'doing' management. (see Figure 1).

Insert Figure 1 about here 
The framework represents the underlying assumptions regarding power when theorising and researching leadership in comparison to management and it is hoped that the framework contributes to greater clarity when distinguishing or connecting the concepts of leadership and management.

\subsection{Quadrant one - managers 'doing' leadership}

In this quadrant management is derived from a positional or assigned perspective and leadership from a personal or emergent perspective. Here management is a position of responsibility in an organisational structure and leadership is something the manager needs to earn through their personal influence. This quadrant represents a traditional view of leadership as a set of behaviours required to be an effective manager, sometimes referred to as managers 'doing' leadership (Alvesson and Sveningsson, 2003a; Alvesson and Sveningsson, 2003b) or managerial leadership (Alvesson and Sveningsson, 2003b; Holmberg and Tyrstup, 2010; Sveningsson and Larsson, 2006; Wright, 1996).

The traditional literature on leadership such as trait theory, style theory, situational or contingency theory, leader-member exchange (LMX) (see Northouse [2007] for a review) and transformational and transactional leadership (see Bass and Riggio [2006] for a review) reflects the attempt of researchers and theory builders to understand managers 'doing' leadership in organisations. Even more contemporary views of leadership being conceptualised as a myth or fantasy (e.g. Sveningsson and Larsson, 2006), even questioning whether leadership exists at all beyond language, discourse 
and attribution (e.g. Alvesson and Sveningsson, 2003b) and exploring the reluctance to lead (Gleeson and Knights, 2008), is still indicative of this quadrant and is still limited to studying managers 'doing' (or in some examples, as above, 'not doing') leadership.

This is important given the growing interest in alternative models of leadership to the formally appointed leader (Fitzsimons et al., 2011) and the subsequent growing literature on 'distributed' or 'dispersed' leadership (see Bolden, 2011 and Thorpe et al., 2011 for reviews). This growth in interest in distributed leadership could illustrate a shift in the literature away from the perspective of researching managers 'doing' leadership. As a result, however, it appears to be developing with little concern for positional aspects of leadership and management which, in turn, positions leadership within unquestioned and unmentioned assumptions about the nature of hierarchy and domination. For example, Bolden and colleagues (2008) have commented that the distributed approach to leadership "argues for a less formalized model of leadership where leadership responsibility is dissociated from the organisational hierarchy. It is proposed that individuals at all levels in the organisation and in all roles can exert leadership influence over their colleagues and thus influence the overall direction of the organisation." If 'dispersed' leadership is to have any real meaning then there is a need to understand it alongside issues of power, knowledge and context (Ray et al., 2004) and in relation to wider issues of ethics (Bolden, 2011), society and community (Edwards, 2011). This four-part representation suggests that there are other broader conceptualisations of leadership and management. 


\subsection{Quadrant two - managers 'becoming' leaders}

In this quadrant both management and leadership are derived from an assigned perspective. Here both management and leadership are seen as positions of responsibility or accountability in an organisation. There appears to be, however, a discourse in the literature that implies 'leadership' framed in this way is seen as a higher 'position' than management, usually referring to the very top levels of organisations - in a sense a figurehead role. As Senge (1999: 15) has highlighted - "In business today, the word 'leader' has become a synonym for top manager. When people talk about 'developing leaders' they mean developing prospective top managers."

Thorpe et al. (2011), go on to point out that the majority of leadership research over the last 50 years has been focused on the organisational or hierarchical assumption, where leadership is being represented by a figurehead, top-down image within organisations. The view that leadership is viewed as to be the 'head of an organisation' has been evident in the literature for some time (e.g. Barnard, 1948; Morris and Seeman, 1950) and it has been proposed that leadership at the higher levels of organisations is more critical than leadership at lower levels (Hall, 1987; Sinha, 1995; Thomas, 2003). This argument is based on viewing organisational positions as hierarchically arranged and therefore have corresponding degrees of authority vested in them. If leadership is taken to be primarily an influence process, the top-level people are in a better position to influence a larger number of subordinates than those below them. The former have a larger and more effective span of authority and control over 
employees, resource allocation and policy decisions (Sinha, 1995). This is a point highlighted by Bedeian and Hunt (2006), whereby they point out that the assumption is taken by earlier researchers (e.g. Morris and Seeman, 1950) that leaders were toplevel organisational members. They go on to outline the limiting nature of viewing leadership in this manner which was stressed by the researchers originally (e.g. Morris and Seeman, 1950) and later by other scholars (e.g. Hollander and Julian, 1970).

This paper, on the other hand, contends that research in this area could be fruitful and should work towards an understanding of what makes the difference between positions being referred to as 'manager' and 'leader' in an organisation - what informs this change in discourse? At what stage do managers get to a position in an organisation whereby they are referred to as leaders and why? And what happens to the self identity of the manager as a result? Do they then see themselves as a leader or as a manager?

As discussed earlier, much of the leadership literature fails to adequately address the issue of power, particularly at what is termed a 'deep structure' level (e.g. Clegg, 1989; Deetz, 1985). Surface-level structures are defined as being readily identifiable, such as those evident in organisational charts or worker's job title, objectives, and goals. Deep structures on the other hand are defined as forms of constraint that are less readily identifiable (Clegg, 1989; Deetz, 1985). Future research therefore could develop a more empirical understanding of the deep structures that mark the transference of being identified as a 'manager' to being identified as a 'leader' from a positional or assigned perspective in organisations. 
There may also be important links to the concept of 'organisational becoming' (Tsoukas and Chia, 2002) where change is conceptualised as being a normal condition for organisations and that organisations are consequently in a perpetual state of 'becoming'. This may relate to quadrant two where instead of leadership being about creating change and management relating to the status quo (e.g. Kotter, 1990), both management and leadership are seen as being in a perpetual process of becoming (e.g. Kempster and Stewart, 2010). This emerging research area into 'leadership becoming' may shed further light on the possible tensions and challenges inherent in these complex processes of organisational change that involve personal as well as position aspects of power. This obviates the need to categorise 'leading' and 'managing' or 'leadership' and 'management' into clichéd and trite generalisations, based on basic models of change, which has plagued the discussion in the literature for years. Indeed, recent publications have challenged the notion of leadership being about creating change and offer a view of leadership in the resistance of change (Levay, 2010; Zoller and Fairhurst 2007).

\subsection{Quadrant three - 'being' managers and leaders}

In quadrant three both the concepts of management and leadership are derived from an emergent perspective. Indeed, this quadrant is reminiscent of calls for researchers to respond to decouple leadership from the managerial role (Fairhurst, 2009; Zoller and Fairhurst, 2007). Here the description of management is markedly different from the description of a role in an organisation instead the description of management is one of 
a mechanism for human beings to cope, 'to get by' (Mangham, 1986; Watson, 1994, 2001), as has been elaborated by Watson (1994) - "When we talk of management or managing in the context of business and other work organisations we think of the work of initiating and organising tasks so that goods and services get produced. But there is an echo of another sense of managing: that of managing as coping, as 'getting by'."

It seems that management is about uncertainty reduction. This is not confined just to an organisational perspective: the personal power or emergent or informal perspective would advocate this is also concerned with uncertainty reduction in one's own life. There is an activity of managing, therefore, that can be performed with or without the formal labels of 'manager' (Easterby-Smith, 1994)

The identity and activity of management as a result is not derived from organisational power systems but as a self-oriented phenomenon. Similarly, the activity and identity of leadership is also described here as 'emergent', free from any organisational authority. Yet, how does it differ from management in this context? If management is 'getting by' or coping then is leadership enabling others to 'get by' or cope? The term 'emergent leadership' is used regularly throughout the literature on leadership but it fails to make a tangible proposition as to how 'emergent' or 'informal' leadership and 'formal' leadership differ.

There is little reference to constructs of the nature of quadrant three in the literature that discusses the differences or similarities between leadership and management. This is therefore a fertile area for research and discussion. We recommend that in this quadrant leadership and management are inter-linked: the ability for a person to cope 
or 'get by' may have an impact on his or her identity as a leader (Ford et al., 2008). For example, concepts such as self-awareness (Fletcher and Baldry, 2000), selfconfidence and self-coping (Edwards et al., 2002) have been posited as being contributory to the identity of being a 'leader'. Self awareness especially is seen as being linked to managerial success (Yammarino and Atwater, 1997) and leadership effectiveness (Alimo-Metcalfe, 1998; Carless et al., 1998; Church, 1997; Church and Waclawski, 1999, Fletcher, 1997; Fletcher and Baldry, 2000). This being-centred perspective of leadership is emerging in the literature (Fry and Kriger, 2009). It is, nonetheless, based on abstract notions of spirituality as opposed to real-lived experiences of managers and leaders in organisations. Further theoretical discussion and empirical research based around the notion of 'being' in organisations therefore appears warranted.

\subsection{Quadrant four - leaders 'doing' management}

In this quadrant leadership is constructed from an assigned perspective and management from an emergent perspective. Here leadership is constructed as a position of responsibility or accountability in an organisation (usually at the top levels) a figurehead role, whereas management is seen as personal ability to cope or 'get by'.

Quadrant four is where a significant body of biographical business, management and political books have been published, yet little time has been invested in empirical research or theoretical discussion. As Salaman (2004) points out, there has been an explosion of interest in biographies of charismatic business 'leaders' (e.g. Feiner, 2005; 
Krames, 2001; Leighton, 2007). These works celebrate the contributions of specific individuals to the success of large organisations (Salaman, 2004). There is a similar trend with biographies of political leaders (e.g. Mandela, 1994; Mowlam, 2002; Obama, 2007) and the contribution they have made to their respective nations. These biographies usually provide an insight as to the personal journey undertaken which, in turn, has the potential to provide some idea of how these leaders 'got by' through their personal management ability. These accounts could offer more to research regarding leadership and management based in this quadrant. Indeed, Watson (2009), in his recent paper regarding narrative and life stories emphasises the importance of autobiography as a research method. This quadrant, therefore, also reflects the importance of ethnographic research in leadership and management research (e.g. Kempster and Stewart, 2010). This epistemological approach may hold the key to understanding this quadrant where there is an understanding of personal management ability and the contribution it makes to one assuming a top level position in an organisation. The growing literature as to how managers learn to lead (e.g. Kempster, 2009) could well provide the impetus to better understand this quadrant.

\section{Implications for Further Research}

There are a number of implications stemming from this framework of the leadership and management debate. Firstly, the framework proposes that it is crucial that researchers make explicit which construct of leadership or management they are discussing or researching, a need highlighted by Bedeian and Hunt (2006). This 
impacts on how leadership and management are viewed and clarification may reduce the confusion highlighted at the beginning of this paper. We believe that the framework provides a useful tool that might reduce the possibility of confusion or cross purposes when studying leadership and management. The paper also provides a reference for researching the relationships between leadership and management in practice. For instance, further research and theory development could develop an understanding of the transition between the concepts of 'doing' and 'being' a leader or a manager or leadership and management in practice. Here we recognise the use of ethnographic (e.g. Hammersley and Atkinson, 2007) and auto-ethnographic (e.g. Chang, 2008) forms of data collection to further develop an understanding of the 'lived' experience of doing, being and becoming managers and leaders in organisations (e.g. Kempster, 2009, Kempster and Stewart, 2010).

As stated earlier, whether leadership and management are similar or different (e.g. Bennis, 1989; Bennis and Nanus, 1985; Hickman, 1990; Kotter, 1988, 1990; Rost, 1991; Zaleznik, 1977) appears to be dependent upon which power construct underlies each phenomenon - either assigned or emergent. For example, management and leadership appear similar when the assumption about power is similar. This can be seen from the four-part framework; leadership and management appear similar in quadrant two (top managers becoming leaders) because they are derived from the same power source; positional power. They also appear similar in quadrant three (being managers and leaders), where in both cases leadership and management identities are derived from personal power. Where the underlying power constructs are 
different, quadrant one (managers doing leadership) and quadrant four (leaders doing management), the concepts of leadership and management are more easily differentiated, although still connected; managers in organisations need to have well developed leadership capability or a well developed leadership identity.

To date, with the possible exception of the work of Grint $(2005,2008)$, it appears that most of the literature on the debate regarding the similarities and differences between leadership and management appear to reside in quadrant one (managers doing leadership) (e.g. Bass, 1985). Even the debate regarding transactional (management) and transformational (leadership) distinctions (Alimo-Metcalfe, 1998; Bryman, 1992; Gill, 2006; Sadler, 1997) resonate with this quadrant. Factors indicative of transactional leadership, such as contingent reward and management-by-exception are, in part, dependent on managerial authority in organisations. It is no surprise that Bedeian and Hunt (2006) therefore concluded that leadership is a subset of management. This paper advises a much broader view and further research is needed in understanding the similarities and differences between concepts and identities of leadership and management derived from quadrants two, three and four. For instance, the work on problem solving (Grint, 2005, 2008) and leadership and management could well indicate the start of this line of research. This could explain the differences between leadership and management inherent in quadrant three, where management and leadership concepts and identities are derived from personal power sources. Further research and reflection should take account of this work. 
In relation to quadrants two and three, further research and theory development is also needed in understanding the concepts at a deeper level where the power constructs are more detailed, such as - charismatic power (Yukl, 1994), gender, network, decision process, boundary management, uncertainty, control of technology, control of counter-organisations power (Morgan, 1986), sexual power (Foucault, 1984), knowledge and information power (Jackson and Carter, 2000; Morgan, 1986;

Pettigrew, 1972), ecological control power (Cartwright, 1965; Oldham, 1976), and truth power (Jackson and Carter, 2000).

Further research should also appreciate a deeper level of understanding with regards to more sociological, post-structural and critical perspectives on power, such as symbolic power (e.g. Bourdieu,1991; Pfeffer, 1981; Pondy, 1978; Weick,1979), disciplinary and bio-power (Foucault 1979; 1984) and Lukes' (2005) three dimensional view of power.

Ray et al., (2004) have advocated that much of the leadership literature is devoid of a critical discussion of power. We have responded. Ray et al., (2004), nevertheless, go on to suggest that the connection between power and leadership is least evident and most needed in the area of 'dispersed' or 'distributed' leadership. This paper has relevance to this area of the literature, such as reflections on the framework highlighted in this paper suggest there is a need to extend the nature of distributed leadership conditions for its development and effectiveness, and what it adds to our understanding of leadership in organisations. 


\section{Conclusions}

This paper has reviewed the literature around conceptualising leadership and management. The paper has provided a potential solution to this problem by uncovering a 'missing link', omitted from the leadership literature; where assumptions about power related to management are of a personal or 'non-work' perspective. From this discussion a four-part framework of how leadership and management can be conceptualised was developed. This framework enables more clarity in understanding attempts to distinguish leadership and management and has potential in providing a common method for categorising leadership research within management studies. The paper contributes by providing a framework that reduces the complexity and confusion that has been endemic in both literatures. This could provide the impetus for developing meaningful connections between psychological and sociological approaches to the study of management and leadership in organisations - linking action - 'doing' - and identity - 'being' - through a process of 'becoming' based on lived experiences.

\section{References}

Alimo-Metcalfe, B. (1998), 360-degree feedback and leadership development, International Journal of Selection and Assessment, 6: 35-44.

Alvesson M and Sveningsson, S. (2003a), Managers doing leadership: The extraordinarisation of the mundane, Human Relations, 56: 1435-1459. 
Alvesson, M. and Sveningsson, S. (2003b), The great disappearing act: difficulties in doing “leadership", Leadership Quarterly, 14: 359-381.

Alvesson, M. and Willmott, H. (1996), Making Sense of Management: A Critical Introduction, London: Sage.

Antonakis, J. and House, R.J. (2002), The full-range leadership theory: The way forward. In: Avolio BJ and Yammarino FJ (eds.) Transformational and Charismatic Leadership: The Road Ahead. Boston: JAI Press.

Barnard, C. (1948), The nature of leadership. In: Barnard C (ed.) Organisation and Management: Selected Papers. Boston: HBR Press.

Bass, B.M. (1985), Leadership and Performance Beyond Expectations. New York: The Free Press.

Bass, B.M. (1990), Bass and Stogdill's Handbook of Leadership: Theory, Research, and Managerial Applications, third edition. New York: Free Press.

Bass, B.M. and Riggio, R. (2006), Transformational Leadership, $2^{\text {nd }}$ edn. Mahwah: Lawrence Erlbaum.

Bavelas, A. (1959), Leadership: Man and function. Administrative Science Quarterly 4: 491-498.

Bedeian, A.G. and Hunt, J.G. (2006), Academic amnesia and vestigial assumptions of our forefathers, Leadership Quarterly, 17: 190-205.

Bennis, W.G. (1989), On Becoming a Leader. Wilmington: Addison-Wesley.

Bennis, W.G. and Nanus, B. (1985), Leaders: The Strategies for Taking Charge. New York: Harper and Row. 
Bolden, R. (2011), Distributed leadership in organisations: A review of theory and research, International Journal of Management Reviews, 13(3): 251-269.

Bolden, R., Petrov, G. and Gosling, J. (2008), Developing Collective Leadership in Higher Education: Final Report. London: Leadership Foundation for Higher Education.

Bourdieu, P. (1991), Language and Symbolic Power. Cambridge: CUP.

Brocklehurst, M., Grey, C. and Sturdy, A. (2009), Management: The work that dares not speak its name, Management Learning, 41: 7-19.

Bryman, A. (1986), Leadership and Organisations. London: Routledge.

Bryman, A. (1992), Charisma and Leadership in Organisations. London: Sage.

Burns, J.M. (1978), Leadership. New York: Harper and Row.

Cammock, P., Nilakant, V. and Dakin, S. (1995), Developing a lay model of managerial effectiveness: A social constructionist perspective, Journal of Management Studies, 32: $443-474$.

Carless, S.A., Mann, L. and Wearing, A.J. (1998), Leadership, managerial performance and 360-degree feedback, Applied Psychology: an International Review, 47: 481496.

Cartwright, D. (1965), Influence, leadership and control. In: March JG (ed.) Handbook of Organisations. Chicago: Rand McNally.

Chang, H.V. (2008), Autoethnography as Method. Walnut Creek: Left Coast Press.

Church, A.H. (1997), Managerial self-awareness in high-performing individuals in organisations, Journal of Applied Psychology, 82: 281-292. 
Church, A.H. and Waclawski, J. (1999), The impact of leadership style on global management practices, Journal of Applied Social Psychology, 29: 1416-1443.

Clegg, S.R. (1989), Frameworks of Power. London: Sage.

Clegg, S.R. and Ross-Smith, A. (2003), Revising the boundaries: Management education and learning in a post-positivist world, Academy of Management Learning and Education, 2: 85-98.

Cooper, C. (2011), Management research in the UK: A personal view, British Journal of Management, 22: 343-354.

Deetz, S. (1985), Critical-cultural research: New sensibilities and old realities, Journal of Management, 11: 121-136.

Drucker, P.F. (1988), Management and the world's wor,. Harvard Business Review, 66: 65-77.

Easterby-Smith, M. (1994), Evaluating Management Development, Training and Education, $2^{\text {nd }}$ edn. Aldershot: Gower.

Edwards, G.P. (2011), Concepts of Community: A Framework for Contextualising Distributed Leadership, International Journal of Management Reviews, 13(3): 301 312.

Edwards, G.P., Winter, P.K. and Bailey, J. (2002), Leadership in Management. Rosson-Wye: The Leadership Trust Foundation.

Fairhurst, G.T. (2009), Considering context in discursive leadership research. Human Relations 62: 1607-1633.

Feiner, M. (2005), The Feiner Points of Leadership. New York: Business Plus. 
Festinger, L. (1954), A theory of social comparison processes, Human Relations, 7: 117-140.

Fitzsimons, D., Turnbull James, K. and Denyer, D. (2011), Alternative approaches for studying shared and distributed leadership, International Journal of Management Reviews, 13(3): 313-328.

Fletcher, C. (1997), Self-awareness - a neglected attribute in selection and assessment? International Journal of Selection and Assessment, 5: 183-187.

Fletcher, C. and Baldry, C. (2000), Self-awareness in the context of multi-source feedback, Journal of Occupational and Organisational Psychology, 73: 303-319.

Ford ,J., Harding, N. and Learmonth, M. (2008), Leadership as Identity. Basingstoke: Palgrave.

Foucault, M. (1979), Governmentality, Ideology and Consciousness, 6: 5-21.

Foucault, M. (1984), The History of Sexuality: An Introduction, Harmondsworth: Peregrine.

French, J.R.P. and Raven, B. (1959), The bases of social power. In: Cartwright D (ed.) Studies in Social Power. Ann Arbor: University of Michigan.

Fry, L. and Kriger, M. (2009), Towards a theory of being-centred leadership: Multiple levels of being as context for effective leadership, Human Relations, 62: 1667-1696.

Ghoshal, S. (2005), Bad management theories are destroying good management practices, Academy of Management Learning and Education, 4: 75-91.

Gill, R. (2006), Theory and Practice of Leadership. London: Sage. 
Gleeson, D. and Knights, D. (2008), Reluctant leaders: an analysis of middle managers' perceptions of leadership in further education in England. Leadership 4: 49-72.

Gordon, R. (2002), Conceptualising leadership with respect to its historical-contextual antecedents, Leadership Quarterly, 13: 151-167.

Grey, C. (1999), We are all managers now; We always were: On the Development and Demise of Management, Journal of Management Studies, 36: 561-585.

Grint, K. (1995), Management: A Sociological Introduction. Cambridge: Polity.

Grint, K. (2005), Problems, Problems, Problems: The Social Construction of Leadership, Human Relations, 58: 1467-1494.

Grint K. (2008), Leadership, Management and Command: Re-thinking D-Day. Basingstoke: Palgrave.

Hales, C. (1986), What do managers do? A critical review of the evidence, Journal of Management Studies, 23: 88-115.

Hales, C. (1999), Why do managers do what they do? Reconciling evidence and theory in accounts of managerial work, British Journal of Management, 10: 335-350.

Hall, R.H. (1987), Organisations: Structures, Processes and Outcomes. Englewood Cliffs: Prentice-Hall.

Hammersley, M. !nd Atkinson, P. (20079, Ethnogbaphy: Principles i Ppactice.OLondono Routledge.

Hickman, C.R. (1990), Mind od a manageò, soul of a le 'der. New York: Wiley. Hollander, E.P. and Juiiao, J.W. (1960) 
Studies in leader leGitkmagy, influgnce, and injovation, Advances in Exqerimenval0Social Psychology 5:(33-69.

Hollander, E.P. and Ofdermann, L.R. (1993), Power and!leadershiq in(obganisations. In: Rosenbach WE anD Taylor RL (eds.) $\neg$ Contemporary Issues in Leadership, $3^{\text {rd }}$ edn. Boulder: Westview.

Holmberg, I.`and Tyrstrup, M. (20!0), Weld 4hen`- What now? An everyday approach to managerial!meadership-\$Leadership, 6(4): 353-s72.

House( R.J. and Baetz, M.L. (1979), Leaderrhip: Some empirical genEralisatkons and new reseirch directionó. In: Staw BW (ed.) Research ij Organisaôional Behaviour (Vol.1). Greenwiah: JAI(Press.

Hackson,\$N. aod Carter, P. (2000), Rethinking Organis!tional Rejaviour. LondOn: Pearsonn

Jepson, D. (2009). Luadership context: the importance of departments, Leadership and Organisation Development Journal, 30: 36-52.

Jepson, D. (2010), The importance of national language as a level of discourse within individuals' theorising of leadership - a qualitative study of German and English employees, Leadership 6: 425-445.

Judge, T.A. and Bono, J.E. (2003), Self concordance at work: Toward understanding the motivational effects of transformational leaders, Academy of Management Journal, 46: 554-571. 
Judge, T.A., Bono, J.E., Ilies, R. and Gerhardt, M.W. (2002). Personality and leadership: A qualitative and quantitative review, Journal of Applied Psychology, 87: 765-780.

Kempster, S. (2009), How Managers have Learnt to Lead: Exploring the Development of Leadership Practice. Basingstoke: Palgrave.

Kempster, S. and Stewart, J. (2010), Becoming a leader: A co-produced autoethnographic exploration of situated learning of leadership practice, Management Learning, 41: 205-219.

Kort, E.D. (2008), What, after all, is leadership? 'Leadership' and plural action, Leadership Quarterly, 19: 409-425.

Kotter, J.P. (1988), The Leadership Factor. New York: Free Press.

Kotter, J.P. (1990), A force for change: How leadership differs from management. New York: Free Press.

Krames, J.A. (2001), The Jack Welch Lexicon of Leadership. New York: McGraw-Hill. Leighton, A. (2007), On Leadership. London: Random House.

Levay, C. (2010), Charismatic Leadership in resistance to change, Leadership Quarterly 21: 127-143.

Lukes, S. (2005), Power: A Radical View. London: Palgrave.

Mandela, N. (1994), Long Walk to Freedom. London: Abacus.

Mangham, I.L. (1986), Power and Performance in Organisations. Oxford: Blackwell. Mant, A.D. (1977), The Rise and Fall of the British Manager. London: Macmillan. 
Mintzberg, H. (1980), The Nature of Managerial Work. Englewood Cliffs: Prentice Hall.

Morgan, G. (1986), Images of Organisation. New York: Sage.

Morris, R.T. and Seeman, M. (1950) The problem of leadership: An interdisciplinary approach. American Journal of Sociology 56: 149-155.

Mowlam, M. (2002), Momentum: The Struggle for Peace, Politics and the People. London: Hodder and Stoughton.

Northouse, P.G. (2007), Leadership: Theory and Practice. Thousand Oaks: Sage.

Obama, B. (2007), Dreams from my Father. Edinburgh: Canongate.

Oldham, G.R. (1976), The motivational strategies used by supervisors: Relationships to effectiveness indicators, Organisational Behaviour and Human Performance, 15: 6686.

Osborn, R.N., Hunt, J.G. and Jauch, L.R. (2002), Toward a contextual theory of leadership, Leadership Quarterly, 13: 797-837.

Osborn, R.N. and Marion, R. (2009), Contextual leadership, transformational leadership and the performance of international innovation seeking alliances, Leadership Quarterly, 20: 191-206.

Pettigrew, A. (1972), Information control as a power resource, Sociology, 6: 187-204.

Pfeffer, J. (1981), Management as symbolic action: The creation and maintenance of organisational paradigms. In: Cummings LL and Staw BM (eds.) Research in Organisational Behaviour (Vol.3). Greenwich: JAI Press 
Pondy, L.R. (1978), Leadership is a language game. In: McCall MW Jr and Lombardo MM (eds.) Leadership: Where else can we go? Durham: Duke University Press.

Porter, L.W. and McLaughlin GB (2006), Leadership and the organisational context: Like the weather? Leadership Quarterly, 17: 559-576.

Pye, A. (2005), Leadership and organising: Sensemaking in action, Leadership, 1: 3150.

Quinn, R.E. (1984), Applying the competing values approach to leadership: Toward an integrative framework. In: Hunt JG, Hosking DM, Schriesheim CA and Stewart R (eds.) Leaders and Managers: International Perspectives on Managerial Behaviour and Leadership. New York: Pergamon.

Raven, B.H. (1992), A power/interaction model of interpersonal influence: French and Raven thirty years later, Journal of Social Behaviour and Personality, 7: 217-244.

Raven, B.H. (1993), The bases of power: Origins and recent developments, Journal of Social Issues, 49: 227-251.

Ray, T., Clegg, S. and Gordon, R. (2004), A new look at dispersed leadership: Power, knowledge and context. In: Storey J (ed.) Leadership in Organisations: Current Issues and Key Trends. London: Routledge.

Rost JC (1991), Leadership for the twenty-first century. Westport: Praeger.

Russell B (1938), Power: A New Social Analysis. London: Allen and Unwin.

Sadler, P. (1997), Leadership. London: Kogan Page. 
Salaman, G. (2004), Competences of managers, competences of leaders. In: Storey J (ed.) Leadership in Organisations: Current Issues and Key Trends. London: Routledge.

Schein, E.H. (2004), Organisational Culture and Leadership, $3^{\text {rd }}$ edn. San Francisco: Jossey-Bass.

Segal, D.R. (1981), Leadership and Management: Organisation Theory. In: Buck JH and Korb LJ (eds.) Military Leadership (pp. 41-69). Beverley Hills, CA: Sage.

Senge, P. (1999), The Dance of Change: The Challenges of Sustaining Momentum in Learning Organisations. London: Nicholas Brealey.

Sinha, J.B.P. (1995), The Cultural Context of Leadership and Power. New Dehli: Sage.

Sturdy, A. and Grey, C. (2003) Beneath and beyond organisational change management: Exploring alternatives, Organisation, 10: 759-770.

Sveningsson, S. and Larsson, M. (2006), Fantasies of leadership: Identity at work, Leadership, 2: 203-224.

Thomas, A.B. (2003), Controversies in Management: Issues, Debates, Answers, $2^{\text {nd }}$ edn. London: Routledge.

Thorpe, R., Gold, J. and Lawler, J. (2011), Locating distributed leadership, International Journal of Management Reviews, 13(3): 239-250.

Tsoukas, H. (1994), What is management? An outline of a meta-theory, British Journal of Management, 5: 289-301.

Tsoukas, H. and Chia, R. (2002), On organisational becoming: Rethinking organisational change, Organisation Science, 13: 567-582. 
Watson, T.J. (1994), Managing, crafting and researching: words, skills and imagination in shaping management research, British Journal of Management, 5: 77-87.

Watson, T.J. (2001), In Search of Management: Culture, Chaos and Control in Managerial Work, revised edn. London: Thomson Learning.

Watson, T.J. (2009), Narrative, life story and manager identity: A case study in autobiographical identity work, Human Relations, 62: 425-452.

Weick, K.E. (1979), Cognitive processes in organisations. In: Staw B (ed.) Research in Organisational Behaviour (Vol.1). Greenwich: JAI Press.

Weick, K.E. (1993), The collapse of sensemaking in organisations: The Mann Gulch Disaster, Administrative Science Quarterly, 38: 628-652.

Whitley, R. (1984) The fragmented state of management studies: Reasons and consequences. Journal of Management Studies 21: 331-348.

Willmott, H. (1984), Images and ideals of managerial work: A critical examination of conceptual and empirical accounts, Journal of Management Studies, 21: 349-368.

Wright. P. (1996), Managerial Leadership. London: Routledge.

Yammarino, F.J. and Atwater, L.E. (1997), Do managers see themselves as others see them? Implications of self-other rating agreement for human resources management, Organisational Dynamics, 25: 35-44.

Young, M. and Dulewicz, V. (2008), Similarities and differences between leadership and management: high performance competencies in the British Royal Navy, British Journal of Management, 19: 17-32. 
Yukl, G.A. (1994), Leadership in Organisations, $3^{\text {rd }}$ edn. Englewood Cliffs: PrenticeHall.

Zaccaro, S.J. and Klimoski, R.J. (2001), The Nature of Organisational Leadership: An Introduction. In: Zaccaro SJ and Klimoski RJ (eds.) The Nature of Organisational Leadership. San Francisco: Jossey-Bass.

Zaleznik, A. (1977), Managers and leaders: are they different? Harvard Business Review, 55: 67-78.

Zoller, H.M. and Fairhurst, G.T. (2007), Resistance as leadership: A critical, discursive perspective, Human Relations, 60: 1331-1360. 
Figure 1. A Conceptual Framework of the Leadership and Management Debate based on Constructs of Power

\section{Assigned Perspective}

Emergent Perspective
1. Where management is seen as a function of a position of authority and leadership is seen as a function of a set of personal characteristics.

Managers 'doing' leadership
2. Where both management and leadership are conceptualised as functions of a position of authority.

Managers 'becoming' leaders

\section{Management}

3. Where both management and leadership are conceptualised as functions of personal characteristics.

'Being' managers and leaders
4. Where leadership is seen as a function of a position of authority and management is seen as a function of a set of personal characteristics.

Leaders 'doing' management

\section{Emergent Perspective}

Assigned Perspective

\section{Leadership}

